\title{
Expression of aquaporin-5 and its regulation in skeletal muscle cells
}

\author{
Sook Mi Hwang ${ }^{1}$, Ryang Hwa Lee ${ }^{1}$, Jin Mi Song ${ }^{1}$, \\ Sick Yoon ${ }^{3}$, You Sun Kim², Sang Joon $\mathrm{Lee}^{2}$, \\ Soo Kyung Kang ${ }^{1}$ and Jin Sup Jung ${ }^{1,4}$ \\ ${ }^{1}$ Research Center for Molecular Medicine, Department of Physiol- \\ ogy, College of Medicine, \\ ${ }^{2}$ Department of Microbiology, College of Natural Science, and \\ ${ }^{3}$ Department of Anatomy, College of Medicine, Pusan National Uni- \\ versity, Pusan 602-739, Korea \\ ${ }^{4}$ Corresponding author: Tel, +82-51-240-7731; \\ Fax, +82-51-246-7734; E-mail, jsjung@hyowon.pusan.ac.kr
}

Accepted 27 February 2002

Abbreviations: AQPs, aquaporins; AQP5, aquaporin-5; ABC, avidinbiotin complex; MAP kinase, mitogen-activated protein kinase

\begin{abstract}
The aquaporins constitute a family of homologous intrinsic membrane proteins that function as highly selective water channels and are highly expressed in tissues where rapid water movement across the cell membrane is required. Molecular mechanism of water transport through the plasma membrane of skeletal muscle is still not clear. This study was designed to identify aquaporin subtypes and their expression regulation in $\mathrm{C} 2 \mathrm{C} 12$ cells, a mouse myoblastic cell line. RT-PCR, immunohistochemistry and Western blot analysis revealed that $\mathrm{C} 2 \mathrm{C} 12$ cells express AQP5. AQP5 expression was increased by induction of $\mathrm{C} 2 \mathrm{C} 12$ differentiation. Exposure of $\mathrm{C} 2 \mathrm{C} 12$ cells to hypertonic solutions induced an increase in AQP5 expression and p38 kinase activation. However, a p38 kinase inhibitor failed to inhibit hyperosmolar induction of AQP5 expression in C2C12 cells. These data indicate that skeletal muscle cells express AQP5 protein and its expression is regulated by differentiation and hypertonic stress.
\end{abstract}

Keywords: C2C12 cells, aquaporin-5, expression, regulation

\section{Introduction}

The aquaporins (AQPs) constitute a family of homologous intrinsic membrane proteins that function as highly selective water channels and are highly expressed in tissues whose function involves rapid water movement across the cell membrane (King and Agre, 1996; Agre et al., 1998; Verkman, 1998; Borgnia et al., 1999). However, the functional significance of AQPs is less clear in nonepithelial cells where rapid fluid transport is probably not necessary. Several AQPs are expressed in nonepithelial cells, including AQP1 in erythrocytes, AQP4 in skeletal muscle plasmalemma, AQP3 in epidermis and urinary bladder, AQP7 in fat, and AQP9 in leukocytes (Borgnia et al., 1999; Yang et al., 2000).

In skeletal muscle, a redistribution of water and ions between body fluid compartments during exercise causes ionic alterations in muscle and blood as water moves from the plasma (Van Beaumont et al., 1973; Kowalchuk et al., 1988) into both the interstitial and intracellular fluid compartments of contracting skeletal muscle. The main driving force for the net flux of water into contracting muscle is the increase in intracellular osmolarity due mainly to the rapid hydrolysis of phosphocreatine as well as to the increase in lactate accumulation resulting from the increased rate of glycolysis (Frigeri et al., 1998). In fact, a high correlation has been found between an increase in muscle lactate and water content (Lindinger et al., 1994). Recently, by using RNase protection assay and immunoperoxidase staining, AQP4 was shown to expressed in skeletal muscle but much less or not at all in smooth and cardiac muscle (Wakayama et al., 1989; Frigeri et al., 1998). AQP4 in rat skeletal muscle is expressed more in fast than slow-twitch fibers and the apparent water permeability is higher in fast-twitch fibers (Yang et al., 2000). In addition, decrease of AQP4 expression was noted in the skeletal muscle of $\mathrm{mdx}$ mice (Wakayama et al., 1989; Yang et al., 2000), a dystrophin-deficient mouse model of Duchenne's muscular dystrophy, and entertained an idea that decreased AQP4 expression might contribute to the pathophysiology and/or pathogenesis of hereditary muscular dystrophies. However, a study using AQP4 deficeint mice provided evidence against a significant role of AQP4 in skeletal muscle physiology in mice (Yang et al., 2000).

AQP5, which was first cloned from salivary glands, has been shown to be expressed in lung, eye and lacrimal glands (Raina et al., 1995). Recently, we found in Genbank Database that an EST clone, which has a homology with AQP5 cDNA was expressed in C2C12 cells, a cell line which was derived from mouse hind limb (Yaffe and Saxel, 1977). In this study we determined the identity of the clone and studied the regulation of its expression in $\mathrm{C} 2 \mathrm{C} 12$ cells. 


\section{Materials and Methods}

\section{C2C12 Cell Culture}

C2C12 cells were obtained from American Type Culture Collection. The cells were grown in DMEM (LIFE Technologies. Inc, Grand Island, NY, USA) containing $10 \%$ FBS at $37^{\circ} \mathrm{C}$ in a $5 \% \mathrm{CO}_{2}$ atmosphere.

\section{RT-PCR}

Total RNA was isolated from $\mathrm{C} 2 \mathrm{C} 12$ cells using RNAzol B (Tel Test. Inc, Friendswood, TX, USA), reverse transcribed into first stand CDNA using oligo dT primer, and amplified by 35 cycles $\left(94^{\circ} \mathrm{C}, 1 \mathrm{~min} ; 50^{\circ} \mathrm{C} 1 \mathrm{~min} ; 72^{\circ} \mathrm{C}\right.$, $1 \mathrm{~min}$ ) of polymerase chain reaction (PCR) using 20 pmole of specific primers. On completion of the PCR reaction, products were examined on $2 \%$ agarose gel. The sequences of the primers used for amplification of AQP5 were 5'-AAC-ACA-ACA-CCA-GGC-AAG-GCC-3' and 5'-GAT-CGG-TTC-TTA-CCC-AGA-AGC-CCA-3'. PCR products were subcloned into pGEM-T easy vectors (Promega Corp., Madison, WI, USA) and the plasmids were sequenced with Sequenase v2.0 (USB, Amersham Life Science, Cleveland, OH, USA).

\section{Western blot analysis}

Confluent monolayers of $\mathrm{C} 2 \mathrm{C} 12$ cells were scraped from culture dish into microfuge tubes. The cells were lysed at $4^{\circ} \mathrm{C}$ in a solution containing $20 \mathrm{mM}$ Tris, $\mathrm{pH} 7.5$, $150 \mathrm{mM} \mathrm{NaCl}, 1 \mathrm{mM}$ EDTA, 1\% Triton X-100, $1 \mathrm{mM}$ phenylmethyl-sulfonyl fluroride, $10 \mu \mathrm{g} / \mathrm{ml}$ leupeptin, 10 $\mu \mathrm{g} / \mathrm{ml}$ aprotinin, and $1 \mathrm{mM}$ sodium orthovanadate. Lysates were centrifuged for $10 \mathrm{~min}$ at $10,000 \mathrm{~g}$ to remove insoluble material.

To determine the expression of AQP5 in tissue, membrane fractions were isolated. Rats were anesthetized with halothane. Salivary glands, lung, liver and skeletal muscles were excised and frozen in liquid nitrogen. Tissue was minced finely and homogenized in homogenizing buffer $(0.3 \mathrm{M}$ sucrose, $25 \mathrm{mM}$ imidazole, $1 \mathrm{mM}$ EDTA, pH 7.2, containing $8.5 \mu \mathrm{M}$ leupeptin and $1 \mathrm{mM}$ phenylmethylsulfonyl fluoride) with a motor-driven Potter-Elvehjem homogenizer. This homogenate was centrifuged in a Beckman L8M centrifuge at $4,000 \mathrm{~g}$ for $15 \mathrm{~min}$ at $4^{\circ} \mathrm{C}$. The supernatants were centrifuged at $200,000 \mathrm{~g}$ for $1 \mathrm{~h}$. The resultant pellet was resuspended in homogenizing buffer. Protein concentration in samples was determined with a protein assay kit (Bio Rad Laboratories, Hercules, CA, USA) using $\gamma$-globulin as the standard.

Proteins $(100 \mu \mathrm{g})$ were suspended in $5 \times$ sample loading buffer $(500 \mathrm{mM}$ Tris, $\mathrm{pH} 6.8,5 \% \beta$-mercaptoethanol, $10 \%$ glycerol, $2.5 \%$ SDS, $0.0125 \%$ bromphenol blue), resolved on a $12 \%$ SDS polyacrylamide gel, electrotransferred to nitrocellulose membranes (HybondECL, Amersham Life Science, Arlinton Heights, IL, USA), and probed with polyclonal AQP5 antibody (Alomon Lab, Chemicon, Temecula, CA, USA) and monoclonal phospho-p44/p42 MAPK antibody (New England Biolabs, Beverly, MA, USA). Immunoreactive bands were detected using horseradish peroxidase-conjugated anti-rabbit or anti-mouse immunoglobulin $G$ antibodies (Amersham Life Science) and visualized by enhanced chemiluminescence (Amersham Life Science). For each gel, an identical gel was run in parallel and subjected to Coomassie staining. The Coomassie-stained gel was used to ascertain identical loading.

\section{Kinase assay}

$\mathrm{C} 2 \mathrm{C} 12$ cells were lysed at $4^{\circ} \mathrm{C}$ in lysis buffer $(20 \mathrm{mM}$ Tris, pH 7.4, $150 \mathrm{mM} \mathrm{NaCl}, 1 \mathrm{mM}$ EDTA, 1 mM EGTA, $1 \%$ Triton, $2.5 \mathrm{mM}$ sodium pyrophosphate, $1 \mathrm{mM} \beta-$ mercaptoethanol, $1 \mathrm{mM}$ sodium ortho vanadate, $1 \mu \mathrm{g} / \mathrm{ml}$ leupeptin and $1 \mathrm{mM}$ phenylmethyl sulfonyl fluoride). Lysates were centrifuged at $13,000 \mathrm{~g}$ for $10 \mathrm{~min}$ at $4^{\circ} \mathrm{C}$, equalized for protein. For c-Jun $\mathrm{N}$-terminal kinase (JNK) assay the supernatant were incubated with an $\mathrm{N}$ terminal c-Jun (1-89) fusion protein bound to glutathione sepharose beads for selectively pulling down JNK from cell lysates (Jeon et al., 2000; Shin et al., 2001). For p38 kinase assay the supernatant was incubated with $1 \mu \mathrm{g}$ anti-p38 antibodies (New England BioLabs, MA, USA) for overnight at $4^{\circ} \mathrm{C}$ followed by incubation with $10 \mu$ of protein $\mathrm{G}$ sepharose bead for $3 \mathrm{~h}$ at $4^{\circ} \mathrm{C}$. The immune complexes were pelleted and washed twice in immunoprecipitation buffer and then twice in kinase buffer. The kinase reaction for JNK assay was carried out in kinase buffer ( $25 \mathrm{mM}$ Tris, pH 7.5, $5 \mathrm{mM} \beta$-glycerophosphate, $2 \mathrm{mM}$ DTT, $0.1 \mathrm{mM}$ sodium ortho vanadate and $10 \mathrm{mM}$ $\mathrm{MgCl}_{2}$ ) containing $100 \mu \mathrm{M}$ ATP, and c-Jun phosphorylation was measured using a phospho-specific c-Jun antibody. The kinase reaction for p38 kinase was done in kinase buffer containing $200 \mu \mathrm{M}$ ATP and $1 \mu \mathrm{g}$ ATF-2 fusion protein. ATF-2 phosphorylation was measured using phospho-ATF-2 antibodies. The antigen-antibody complexes were visualized by chemiluminescence ( $E C L$ detection system, Amersham Life Science).

\section{Immunohistochemistry}

The mice were anesthetized with diethylether. The salivary grands and tongues were removed and rapidly frozen in isopentane cooled with liquid nitrogen. Frozen sections ( 3 and $5 \mu \mathrm{m}$ thick) were cut on a Reichert cryostat and placed on 3-aminopropyltriethoxysilanecoated slides. After being dried, the cryosections were fixed in cold acetone for $10 \mathrm{~min}$ at $-20^{\circ} \mathrm{C}$. $\mathrm{C} 2 \mathrm{C} 12$ cells grown on gelatin-coated glass slides were fixed in cold acetone for $3 \mathrm{~min}$. Immunostaining was performed by the streptavidin-biotin complex (ABC) method. In brief, the slides were incubated for $10 \mathrm{~min}$ in a solution of phosphate-buffered saline (PBS) containing $0.3 \% \mathrm{H}_{2} \mathrm{O}_{2}$. 
After a wash in PBS, the sections and slides were incubated with a bovine serum albumin (BSA) solution (Sigma, $10 \mathrm{mg} / \mathrm{ml}$ in PBS). The slides were incubated for $16-18 \mathrm{~h}$ at $4^{\circ} \mathrm{C}$ with the primary polyclonal AQP5 antibody (Alomon Lab, Chemicon, Temecula, CA, USA). Following incubation with the primary antibodies, the sections were incubated with biotinylated anti-rabbit antibodies (Jackson Immunoresearch Labs., West Grove, PA, USA; Vector Labs., Burlingame, CA, USA). Then the sections were incubated for 60 min with an $A B C$ reagent (Vectastain Elite kit, Vector Labs.) according to the manufacturer's instructions. After a PBS rinse, the sections were developed with a $0.05 \%$ 3-3'-diaminobenzidine- $\mathrm{H}_{2} \mathrm{O}_{2}$-medium under microscopical control. Afterwards, the sections were either counterstained with Harris' hematoxylin or not counterstained, and mounted in a xylene-based mounting medium (Permount).

\section{Results}

\section{Sequence alignment of a PCR product from $\mathrm{C} 2 \mathrm{C} 12$ cells}

In the GenBank database we found an EST clone (AA518462) obtained from mouse $\mathrm{C} 2 \mathrm{C} 12$ cells that has sequence similarity with the AQP5 cDNA. To confirm whether $\mathrm{C} 2 \mathrm{C} 12$ cells expressed AQP5, we designed the PCR primers from the DNA sequence of clone AA518462. PCR amplification yielded the 262 bps products in reverse-transcribed cDNA obtained from total RNA of C2C12 cells, but not in total RNAs itself (Figure 1). DNA sequencing of the PCR products revealed that the partial DNA sequence of PCR fragment have $100 \%$ identity with the sequence of mouse AQP5 cDNA (NM 009701), indicating that $\mathrm{C} 2 \mathrm{C} 12$ cells express AQP5 mRNA (Figure 2).

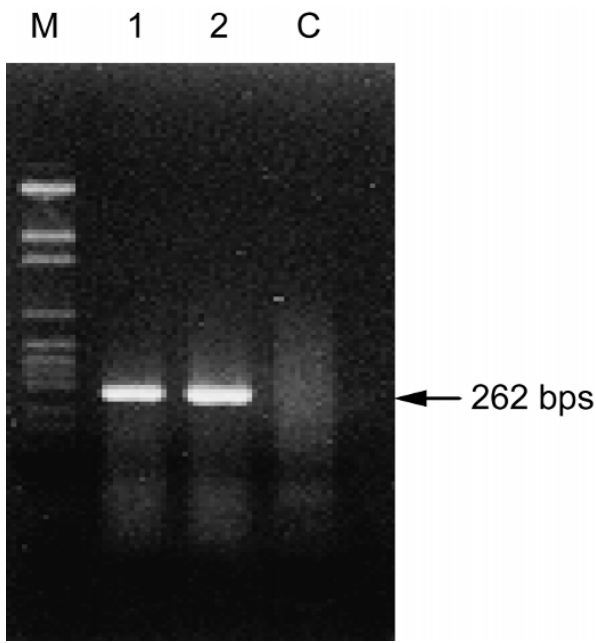

Figure 1. PCR Amplification of clone AA518462 in C2C12 cells. Amplification of AQP5 was conducted using primers for the clone AA518462 (262-bp PCR product). Lane 1 and 2, PCR products amplified from reverse transcribed C2C12 CDNA. M, 100-bp DNA ladder. Lane C, As a negative control, total RNA from $\mathrm{C} 2 \mathrm{C} 12$ cells was amplified without reverse transcription.

\section{Differentiation-induced expression of AQP5 protein in $\mathrm{C} 2 \mathrm{C} 12$ cells}

To examine whether the protein was made from the mRNA in C2C12 cells, Western blot analysis was performed by using polyclonal antibody specific to AQP5 protein. The expected size of AQP5 protein bands were detected in all membrane fractions from lung, salivary glands, hindlimb skeletal muscles and $\mathrm{C} 2 \mathrm{C} 12$ cells (Figure $3 A$ ), supporting the expression of AQP5 in skeletal muscle cells as well as $\mathrm{C} 2 \mathrm{C} 12$ cells. No antibody reactive bands were found in the membrane fractions of liver. Further examination of the salivary gland by immunohistochemistry showed positive staining of acinar cells but neither
clone 1
1 aacaccaggcaagggcgtggtggtggagt taatct tgact t tccagctggccetctgcat 59
11111111111111111111111111111111111111111111111111111111
AQP5 cDNA 871 aacaccaggcaaggccgtggtggtggagttaatcttgact tccagctggcectctgcat 930
111111111111111111111111111111111111111111111111111111111
AA518462 13 aacaccaggcaaggccgtggtggtggagt taatct tgact tccagctgggectctggat 71
clonel $\quad 60$ cttctcctccacggactccegccgcaccagcceggttggetccccag 106
|||||||||||||||||||||||||||||||||||||||||| $\mid$
AQP5 cDNA 931 cttctcctccacggactccegcegcaccagcccggtgggetccccag 977

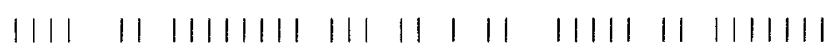
AA518462
72 cttcctcttcacggact tccggeggaacaagccggttgg-tccccag 118

Figure 2. Blast alignments of a PCR product sequence in $\mathrm{C} 2 \mathrm{C} 12$ cells with those of clone AA518462 and mouse AQP5 CDNA. 
A.

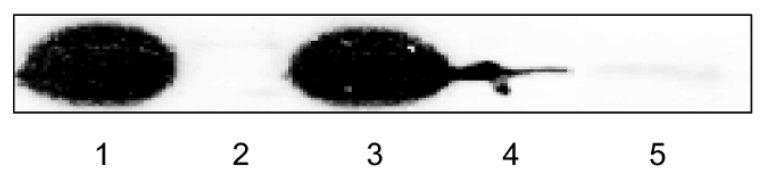

B.

a
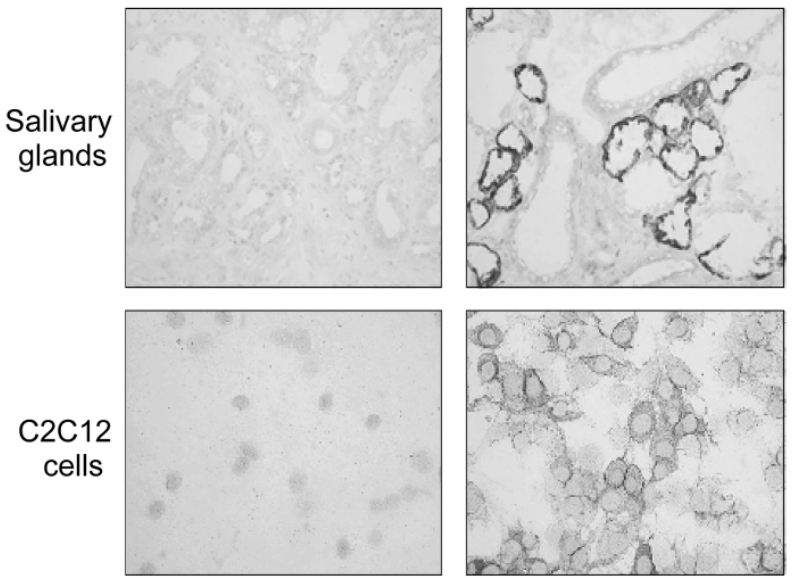

Figure 3. A. Expression of AQP5 protein in various tissues. A. Crude membrane fractions were obtained from lung (lane 1), liver (lane 2), salivary glands (lane 3), C2C12 cells (lane 4) and hind limb skeletal muscles (lane 5 ) by the procedure described in Materials and Methods. B. Anti-rabbitAQP5 antibody labels cryosection (2- to 3- $\mu \mathrm{m}$ sections) of mouse salivary glands and $\mathrm{C} 2 \mathrm{C} 12$ cells ( $\mathrm{a}$ and $\mathrm{b}$ ). Panel a shows immunolabeling controls using anti-AQP5 antibodies preabsorbed with the respective immunizing peptide. No signal can be seen. Magnification: $\times 400$.

the ductal nor blood vessels (Figure 3B), consistent with the previous finding of Funaki et al. (1998). Positive immunoreactivity of AQP5 antibody was also detected in $\mathrm{C} 2 \mathrm{C} 12$ cells. $\mathrm{C} 2 \mathrm{C} 12$ cells were derived from skeletal muscle of mouse hind limb and differentiated rapidly to myotube by withdrawing FBS from medium and adding $2 \%$ horse serum (Yaffe and Saxel, 1977). To examine whether differentiation of $\mathrm{C} 2 \mathrm{C} 12$ cells affect the expression of AQP5 protein, we determined the AQP5 level in the samples obtained on 2nd and 4th day after induction of differentiation. As shown in Figure 4, AQP5 expression increased on the 2nd day after induction of differentiation and declined on the 4th day.

\section{Time course for osmotic induction of AQP5 protein}

Expression of AQP5 was found to be induced by exposure of hypertonic stress in mouse lung epithelial cells (Hoffert et al., 2000). The effect of hypertonic stress on the expression of AQP5 in C2C12 cells were examined by increasing the osmolarity of the culture medium to 500 mOsM. C2C12 cells incubated in the normal medium supplemented with $100 \mathrm{mM} \mathrm{NaCl}$ were harvested at various times for immunoblot. Expression of AQP5 protein was increased by $48 \mathrm{~h}$ after exposure

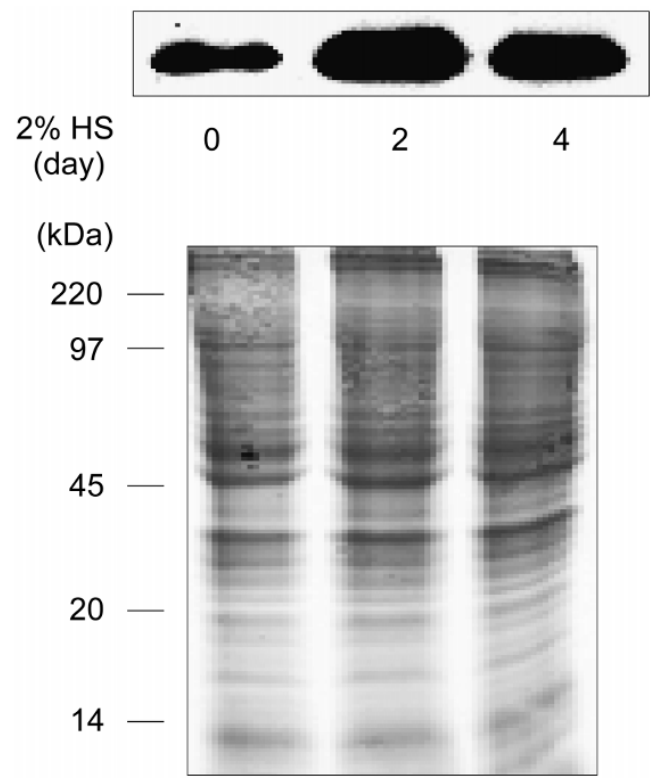

Figure 4. Induction of $\mathrm{AQP} 5$ during differentiation of $\mathrm{C} 2 \mathrm{C} 12$ cells. Differentiation of $\mathrm{C} 2 \mathrm{C} 12$ cells were induced by withdrawal of FBS and addition of $2 \%$ horse serum. At the indicated days cells were harvested in lysis buffer. Protein immunoblot was performed with polyclonal rabbit AQP5 antibody. The underlying SDS PAGE gel showed equal loading of protein samples. Gels were stained with Coomassie brilliant green-G250.
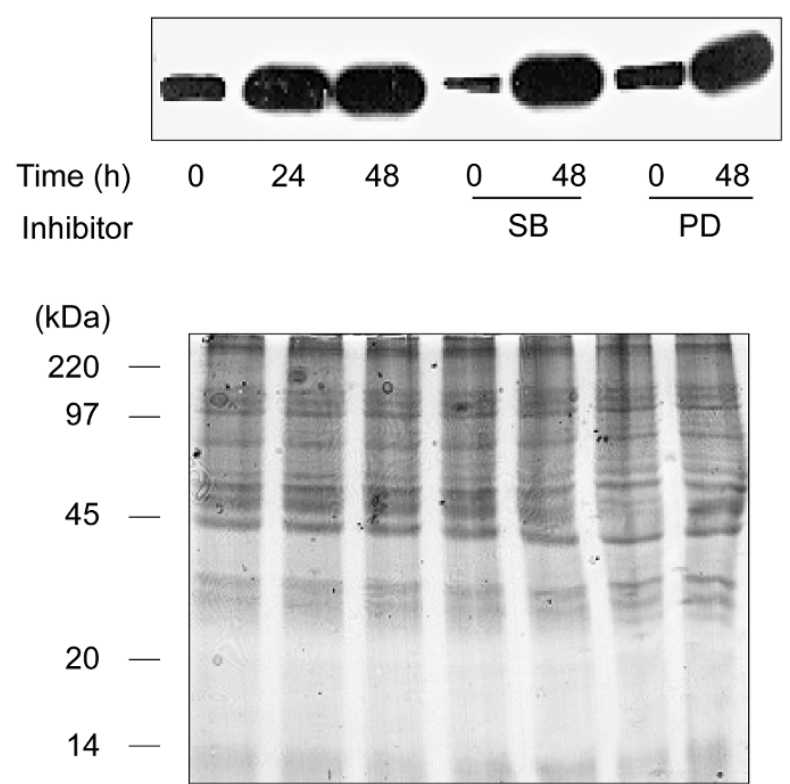

Figure 5. Time course for osmotic induction of AQP5 protein. $\mathrm{C} 2 \mathrm{C} 12$ cells were incubated in hypertonic medium containing $200 \mathrm{mOsM} \mathrm{NaCl}$. At the indiated time, cells were harvested in lysis buffer for protein immunoblot with anti-AQP5 antibody. To determine the effect of a p38 MAP kinase or ERK on hypertonic induction of AQP5 expression. C2C12 cells were incubated in isotonic or hypertonic medium for $48 \mathrm{~h}$ in the presence or absence of SB203580 $(20 \mu \mathrm{M})$ or PD98059 $(50 \mu \mathrm{M})$. Either SB203580 or PD98059 was pretreated for $2 \mathrm{~h}$ before the addition of $\mathrm{NaCl}$. Cells were harvested in homogenization buffer, and protein immunoblots were probed with antiAQP5. The underlying SDS-PAGE gel showed equal loading of protein samples. Gels were stained with Coomassie brilliant green-G250. 

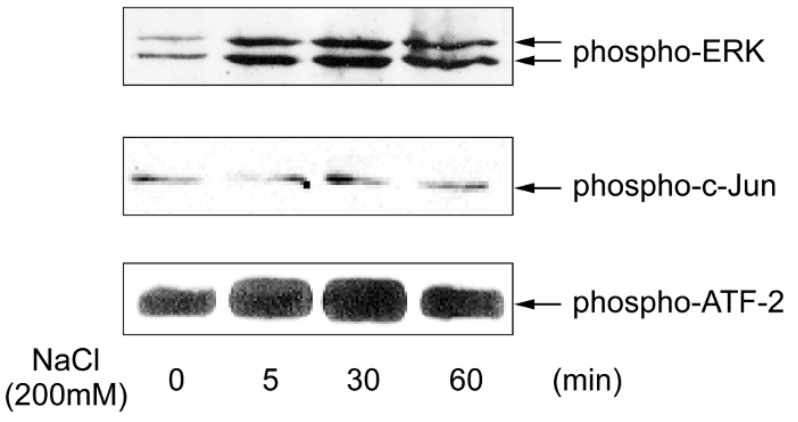

Figure 6. Effect of exposure to hypertonic medium on activity of JNK/SAPK and p38 kinase. $\mathrm{C} 2 \mathrm{C} 12$ cells were exposed to control or hypertonic medium for the indicated times and then harvested in phosphoprotective buffer. Protein immunoblot were performed using antibodies to phospho-ERKs, phospho-c-Jun and phospho-ATF-2, respectively.

to hypertonic medium (Figure 5). A Comassie-staining of an identical gel was used to showl an equal loading of protein into each well. Exposure of $\mathrm{C} 2 \mathrm{C} 12$ cells to hypertonic medium did not induce any significant morphological changes of $\mathrm{C} 2 \mathrm{C} 12$ cells (data not shown).

\section{Effect of exposure to hypertonic medium on activity of ERK, JNK/SAPK and p38 kinase}

Previous reports have shown that all three MAP kinases (ERK, JNK, and p38) can be activated by osmotic stress (Umenishi et al., 1996; Borok et al., 1998; Funaki et al., 1998). In particular, p38 has frequently been implicated in the induction of genes involved in organic osmolyte synthesis and transport (Hamman et al., 1998; Krane et al., 1999). Possible association of MAP kinase-mediated signaling with the induction of AQP5 was first determined for the activation of JNK/SAPK and p38 kinase by exposure of $\mathrm{C} 2 \mathrm{C} 12$ cells to hypertonic medium (500 mOsM). Hyperosmolarity failed to activate JNK/SAPK in C2C12 cells, but increased ERK and p38 kinase activities (Figure 6). However, incubation of $\mathrm{C} 2 \mathrm{C} 12$ cells with 20 mM SB203580, a specific p38 kinase inhibitor, did not reduce basal AQP5 expression and AQP5 induction by hypertonicity (Figure 5 ). In addition, the pretreatment of $\mathrm{C} 2 \mathrm{C} 12$ cells with $50 \mu \mathrm{M}$ PD98059, an inhibitor of ERKs, did not affect AQP induction by hyperosmolarity (Figure 5). These results indicate that activation of JNKI SAPK, ERKs or p38 kinase does not appear to be involved in the hyperosmolarity-induced increase of AQP5 expression in $\mathrm{C} 2 \mathrm{C} 12$ cells.

\section{Discussion}

Discovery of the aquaporin family of water channel proteins has provided insight into molecular mechanisms of membrane water permeability. It is increasingly clear that aquaporins can be rate-limiting for water transport, as evidenced by recent demonstrations in the kidney (Deen et al., 1994; Ma et al., 1998), lung (Bai et al.,
1999), and salivary glands (Ma et al., 1999). AQP5 that was first cloned from salivary glands has shown to be expressed in lung, eye, middle ear epithelium and lacrimal glands besides of salivary glands (Raina et al., 1995; Minami et al., 2001). In this study we first demonstrated that AQP5 is expressed in C2C12 cells by RT-PCR, Western analyis and immunohistochemistry. The primers designed from the DNA sequence of clone AA518462 (obtained from mouse EST project) was used for amplification of AQP5 cDNA in C2C12 cells. Therefore, we believe that the clone can be classified as AQP5 homolog considering possible sequencing error. The upstream and downstream PCR primers to be used in the PCR reaction are located at the different exons of the mouse AQP5 gene (Krane et al., 1999). The amplification of PCR fragments, which have an identical size with that deduced from the cDNA sequence of the mouse AQP5 gene, indicated that the PCR products were amplified from reverse transcribed cDNA, not from contaminated chromosomal DNAs.

Several studies demonstrated that skeletal muscle cells express AQP4 protein (Frigeri et al., 1998). Frigeri et al. (2001) showed that AQP4 expression in skeletal muscle can be subjected to regulation depending on the functional demand, and that its expression is temporally associated with the transition from the slow phenotype to the fast and thus to the glycolytic metabolism of the fiber. These data suggest important roles of AQP4 in skeletal muscle physiology. However, a recent study using AQP4 deficeint mice provided evidence against a significant role of AQP4 in skeletal muscle physiology in mice (Yang et al., 2000). These may be related to presence of other aquaporin homologs in skeletal muscle cells. Western blot analysis in this study showed expression of AQP5 in endogenous skeletal muscle, consistent with the presence of AQP5 in $\mathrm{C} 2 \mathrm{C} 12$ cells derived from mouse hind limb. The data in this study showed that $\mathrm{C} 2 \mathrm{C} 12$ cells express AQP5 and its expression was transiently increased during differentiation of $\mathrm{C} 2 \mathrm{C} 12$ cells. But the expression level of AQP5 in adult skeletal muscles obtained from lower leg was rather limited. Frigeri et al. (1999) showed that AQP4, a major aquaporin in skeletal muscle, is only expressed in fasttwitch fibers, not in slow twitch fibers. By reference, there is a possibility that AQP5 is expressed in the fast twitch fiber only in adult skeletal muscle, and the expression level in adult skeletal muscle may be related to the proportion of fast twitch fiber present in the muscle tissues used. Transient increase of AQP5 expression during differentiation also suggests the possibility that AQP5 may be involved in early stage of myogenic differentiation.

Our study also showed that the expression of AQP5 in $\mathrm{C} 2 \mathrm{C} 12$ cells was upregulated by the increase in osmolarity in culture medium, as was found in lung epithelial cells (Hoffert et al., 2000), which suggest role 
of AQP5 in water movement through sacrolemma during exercise. The signaling mechanisms for hypertonic induction of AQP5 in C2C12 cells were different from that in MLE-15 cells, a lung epithelial cell line. Hoffert et al. (2000) reported that hypertonic stress activated the ERK pathway but not the JNK or p38 MAP kinase pathways in MLE-15 cells. However, the data in this study showed that hypertonic stress increased ERK and p38 kinase activities, and that SB203580, a p38 kinase inhibitor, and PD98059, an ERK inhibitor, failed to inhibit induction of AQP5 expression by hypertonic stress. These data indicate that hypertonic induction of AQP5 in $\mathrm{C} 2 \mathrm{C} 12$ cells is not related with MAPKs activation. Further study will be required to elucidate the mechanism.

\section{References}

Agre P, Bonhivers M, Borgnia MJ. The aquaporins, blueprints for cellular plumbing systems. J Biol Chem 1998;273:14659-62

Bai C, Fukuda N, Song Y, Ma T, Matthay MA, Verkman AS. Lung fluid transport in aquaporin-1 and aquaporin-4 knockout mice. J Clin Invest 1999;103:555-61

Borgnia M, Nielsen S, Engel A, Agre P. Cellular and molecular biology of the aquaporin water channels. Annu Rev Biochem 1999;68:425-58

Borok Z, Lubman RL, Danto SI, Zhang XL, Zabski SM, King LS, Lee DM, Agre P, Crandall ED. Keratinocyte growth factor modulates alveolar epithelial cell phenotype in vitro: expression of aquaporin 5. Am J Respir Cell Mol 1998;18:554-61

Deen PM, Verdijk MA, Knoers NV, Wieringa B, Monnens LA, van Os $\mathrm{CH}$, van Oost BA. Requirement of human renal water channel aquaporin-2 for vasopressin-dependent concentration of urine. Science 1994;264:92-95

Frigeri A, Gropper M, Umenishe F, Kawashima M, Brown D, Verkman AS. Localization of MIWC and GLIP water channel homologs in neuromuscular, epithelial and glandular tissues. J Cell Sci 1995;108:2993-3002

Frigeri A, Nicchia GP, Desaphy JF, Pierno S, De Luca A, Camerino DC, Svelto M. Muscle loading modulates aquaporin4 expression in skeletal muscle. FASEB J 2001;15:1282-84

Frigeri A, Nicchia GP, Verbavatz JM, Valenti G, Svelto M. Expression of aquaporin-4 in fast-twitch fibers of mammalian muscle. J Clin Invest 1998;102:695-703

Funaki $\mathrm{H}$, Yamamoto $\mathrm{T}$, Koyama $\mathrm{Y}$, Kondo D, Yaoita E, Kawasaki K, Kobashi H, Sawaguchi S, Abe H, Kihara I. Localization and expression of AQP5 in cornea, serous salivary glands, and pulmonary epithelial cells. Am J Physiol 1998; 275:C1151-57

Hamman S, Zeuthen T, La Cour M, Nagelhus EA, Ottersen $\mathrm{OP}$, Agre P, Nielsen S. Aquaporins in complex tissues: distribution of aquaporins 1-5 in human and rat eye. Am J Physiol 1998;274:C1332-45

Hoffert JD, Leitch V, Agre P, King LS. Hypertonic Induction of Aquaporin-5 expression through an ERK-dependent pathway.

\section{J Biol Chem 2000;275:9070-77}

Jeon SH, Kim YS, Bae CD, Park JB. Activation of JNK and p38 in rat hippocampus after kainic acid induced seizure. Exp Mol Med 2000;32:227-30

King LS, Agre P. Pathophysiology of the aquaporin water channels. Annu Rev Physiol 1996;58:619-48

Kowalchuk JM, Heigenhauser GJF, Lidinger MI, Sutton JR, Jones NL. Factors influencing hydrogen ion concentration in muscle after intense exercise. J Appl Physiol 1988;65:2080-89

Krane CM, Towne JE, Menon AG. Cloning and characterization of murine Aqp5: evidence for a conserved aquaporin gene cluster. Mamm Genome 1999;10:498-505

Lindinger MI, Spriet LL, Hultman E, Putman T, McKelvie RS, Lands LC, Jones LR, Heigenhauser GJ. Plasma volume and ion regulation during exercise after low-and high-carbohydrate diets. Am J Physiol 1994;266:R1896-906

Ma T, Song Y, Gillespie A, Carlson EJ, Epstein CJ, Verkman AS. Defective secretion of salivary in transgenic mice lacking aquaporin-5 water channels. J Biol Chem 1999;274:20071-74

Ma T, Yang B, Gillespie A, Carlson EJ, Epstein CJ, Verkman AS. Severely impaired urinary concentrating ability in transgenic mice lacking aquaporin-1 water channels. J Biol Chem 1998;273:4296-99

Minami S, Kobayashi H, Yamashita A, Yanagita T, Uezono Y, Yokoo H, Shiraishi S, Saitoh T, Asada Y, Komune S, Wada A. Selective expression of aquaporin 1, 4 and 5 in the rat middle ear. Hear Res 2001;158:51-56

Raina S, Preston GM, Guggino WB, Agre P. Molecular cloning and characterization of an aquaporin cDNA from salivary, lacrimal, and respiratory tissues. J Biol Chem 1995;270:190812

Shin EY, Kim SY, Kim EG. c-Jun N-terminal kinase is involved in motility of endothelial cell. Exp Mol Med 2001;33:276-83

Umenishi F, Carter EP, Yang B, Oliver B, Matthay MA, Verkman AS. Sharp increase in rat lung water channel expression in the perinatal period. Am J Respir Cell Mol Biol 1996;15:673-79

van Beaumont W, Strand JC, Petrofsky JS, Hipskind SG, Greenleaf JE. Changes in total plasma content of electrolytes and proteins with maximal exercise. J Appl Physiol 1973;34: 102-6

Verkman AS. Role of aquaporin water channels in kidney and lung. Am J Med Sci 1998;316:310-20

Wakayama Y, Jimi T, Misugi N, Kumagai T, Miyake S, Shibuya $\mathrm{S}$, Miike T. Dystrophin immunostaining and freeze-fracture studies of muscles of patients with early stage amyotrophic lateral sclerosis and Duchenne muscular dystrophy. J Neurol Sci 1989;91:191-205

Yaffe D, Saxel O. Serial passaging and differentiation of myogenic cells isolated from dystrophic mouse muscle. Nature 1977;270:725-27

Yang B, Verbavatz JM, Song Y, Vetrivel L, Manley G, Kao WM, Ma T, Verkman AS. Skeletal muscle function and water permeability in aquaporin-4 deficient mice. Am J Physiol Cell Physiol 2000;278:C1108-15 